\title{
Erratum: Thoracoscopic surgery for bronchobiliary fistula: a case report
}

\author{
Yen-Shou Kuo ${ }^{1}$, Shih-Chun Lee ${ }^{1}$, Hung Chang ${ }^{1}$, Chung-Bao Hsieh ${ }^{2}$ and Tsai-Wang Huang ${ }^{1 *}$
}

After publication of the article [1] it was discovered that this manuscript was mistakenly given a duplicated citation number. The correct citation of 9:198 has now been updated in all versions of this manuscript. We apologise for any inconvenience caused by this error.

\section{Author details}

'Division of Thoracic Surgery, Tri-Service General Hospital, National Defense Medical Center, Taipei, Taiwan. ${ }^{2}$ Division of General Surgery, Tri-Service General Hospital, National Defense Medical Center, Taipei, Taiwan.

Received: 30 April 2015 Accepted: 6 May 2015

Published online: 26 July 2015

\section{Reference}

1. Kuo Y-S, Lee S-C, Chang H. Thoracoscopic surgery for bronchobiliary fistula: a case report. J Cardiothorac Surg. 2014:9:139.

\footnotetext{
* Correspondence: chi-wang@yahoo.com.tw

'Division of Thoracic Surgery, Tri-Service General Hospital, National Defense Medical Center, Taipei, Taiwan
}

Full list of author information is available at the end of the article

Submit your next manuscript to BioMed Central and take full advantage of:

- Convenient online submission

- Thorough peer review

- No space constraints or color figure charges

- Immediate publication on acceptance

- Inclusion in PubMed, CAS, Scopus and Google Scholar

- Research which is freely available for redistribution 